\title{
Ways of increase of efficiency of process of the vibroextrusion of fibrous concrete
}

\author{
M.T. Dovzhik \\ National Technical University of Ukraine “Igor Sikorsky Kyiv Polytechnic Institute”, str. Polytechnichna, 39, Bldg. 19, \\ Kyiv, 03056, Ukraine \\ Tel.: +380444068451 \\ E-mail: ynk@kpi.ua
}

Article info: received 03.06.2019, revised 18.06.2019, accepted 26.06.2019

Dovzhik, M.T. (2019) Ways of increase of efficiency of process of the vibroextrusion of fibrous concrete 2(43), doi: 10.26909/csl.2.2019.3

The process of mixing the components of the mixture is an important factor affecting the physical and mechanical properties and appearance of the final product. The proposed designs of vibroexcluders for mixing fibrous concrete and the formation of flat products provided analytical formulas for calculating the process of vibration extrusion.

The quantitative criterion of laminar convective mixing, which occurs when vibroexclusion, is the degree of increase in the surface area of the interface between the components, which in turn depends on the total deformation and initial orientation of the surface.

The constructions of vibroextruders are provided for the mixing of a fibrous concrete and forming flat products, and analytical formulas are given for the calculation of the vibroextrusion process.

The construction of a cascade vibrating extruder for the proposed mixing can be applied to a wide range of compositions of fibro concrete mixes, and a specially designed vibratory extruder for forming can significantly improve the longitudinal orientation of dispersed fittings in flat products.

The degree of longitudinal orientation of the fiber in the process of vibroexclusion of fiber concrete can be regulated by the geometry and size of the channels of the vibroexcutter bunker, as well as by the application of special guiding partitions.

Practically the degree of mixing is characterized by the speed of vibration exclusion. Due to the fact that the vibroextrusion mixing does not occur the destruction of fiber reinforcement, as a result of the successive passage of the mixture through several channels, the moment when the vibration excursion velocity stabilizes.

The given analytical dependencies give the possibility of quantitative description of differences in the deformation of the mixture and the final orientation of fibers in the products for the proposed apparatus. The degree of longitudinal orientation fibers need to be set separately for different products, depending on their purpose, and change the degree of orientation is carried out by changing the geometry of the vane bunker vibroextruder.

The results of the work are supposed to be used in the design of a new vibration excretory equipment for mixing fibrous concrete mixtures and the formation of dispersed reinforced products.

Key words: vibroextrusion, fibrous concrete, flat wares.

\section{Шляхи підвищення ефективності процесу віброекструзії фібробетону}

\author{
М.Т. Довжик
}

Національний технічний університет Украӥни “Київський політехнічний інститут”, Київ, Украӥна

Процес змішування компонентів суміші є важливим фактором, що впливає на фізико-механічні властивості і зовнішній вигляд кінцевої продукції. Запропоновані конструкції віброекструдерів для змішування фібробетону і формування плоских виробів, подані аналітичні формули для розрахунку процесу віброекструзії.

Ефективність дисперсного армування збільшується також коли при навантаженні композиційного матеріалу у роботу включається якнайбільше фібр, а цього можна досягти при направленій орієнтації фібр уздовж діючих зусиль у виробі. 
Конструкція каскадного віброекструдера для змішування, що пропонується, може бути застосована для широкого діапазону складів фібробетонних сумішей, а спеціально розроблений віброекструдер для формування дозволяє значно підвищити поздовжнє орієнтування дисперсної арматури у плоских виробах.

\section{Вступ}

Одним 3 напрямків зниження енергоємності виробництва і матеріалоємності виробів є використання принципово нових конструкційних матеріалів, які перевищують за своїми властивостями застосовні в наш час. Дисперсне армування бетону $\epsilon$ сучасним напрямком покращення практично всіх його основних фізико-механічних характеристик за рахунок залучання фібр у спільну роботу з бетоном при виникненні напружень.

У Національному технічному університеті України «Київський політехнічний інститут» був розроблений віброекструзійний спосіб формування фібробетонних виробів, що дозволяє застосовувати будь-які фібри при знижених водоцементних відношеннях і без використання поверхнево-активних речовин. В процесі віброекструзії фібробетону здійснюється природна орієнтація фібр за рахунок деформацій зсуву композиційного матеріалу у каналах бункера віброекструдера.

Процес змішування компонентів суміші $є$ важливим фактором, що впливає на фізико-механічні властивості і зовнішній вигляд кінцевої продукції. Віброекструзійне змішування фібробетонних сумішей, як і багато інших процесів змішування твердих речовин 3 рідинами, волокон 3 полімерами i т. ін. можна розглядати, як змішування рідин [1], оскільки у даному випадку процес змішування полягає, як правило, у розподілі невеликої кількості твердої речовини всередині системи. Кількісним критерієм ламінарного конвективного змішування, що має місце при віброекструзії, є ступінь збільшення площі поверхні розділу між компонентами, яка у свою чергу залежить від сумарної деформації і початкової орієнтації поверхні. Вадою ламінарного конвективного змішування $\epsilon$ нерівномірність зсувних деформацій у всьому об'ємі матеріалу. Для усунення цього недоліку компоненти суміші повторно пропускають через змішувачі, доки не буде досягнуто потрібної якості суміші $[1,2]$.

Ефективність дисперсного армування збільшується також коли при навантаженні композиційного матеріалу у роботу включається якнайбільше фібр, а цього можна досягти при направленій орієнтації фібр уздовж діючих зусиль у виробі. Певної орієнтації фібр у виробі досягають в процесі його формування при направленому вібруванні суміші у формі; коли один з розмірів виробу порівнянний з розмірами фібр при виготовлені у формі; при використанні перегородок для орієнтування в процесі екструзії і віброекструзії; при використанні металевих фібр у магнітному полі; за допомогою пошарового укладання орієнтованих фібр, які знаходяться у водорозчинній плівці і ін. Ступінь поздовжньої орієнтації фібр в процесі віброекструзії фібробетону можна регулювати геометрією і розмірами каналів бункера віброекструдера, а також за рахунок застосування спеціальних орієнтуючих перегородок.

Відповідно до цього поставлена задача статті: 3'ясувати можливі шляхи удосконалення процесу змішування компонентів суміші і забезпечення необхідного орієнтування дисперсної арматури у виробі для підвищення ефективності віброекструзії фібробетону .

Процес простого змішування в умовах ламінарного плину при відсутності дифузії, який здійснюється у плоских збіжних каналах, розглянуто у роботах $[3,4]$.

Недоліком процесу змішання у каналі, що звужується, є нерівномірність деформацій зсуву у всьому об'ємі матеріалу. Необхідна сумарна деформація зсуву для забезпечення якісного змішання залежить від компонентів суміші, а також від матеріалу і питомої поверхні фібр. Для якісного змішування усього об'єму матеріалу (особливо для сильно наповнених фібрами складів) недостатнім є використання одного каналу, що виражається у неповному змочуванні розчином фібр, які знаходяться менше усього в змішувачі.

Практично ступінь змішування характеризується швидкістю віброекструзії. Через те, що при віброекструзійному змішуванні не відбувається руйнування фібрової арматури, в результаті послідовного проходження суміші через декілька каналів настає момент, коли швидкість віброекструзії стабілізується (ріст їі припиняється). Це свідчить про повне змочування фібр розчином. Так, при проектуванні дослідно-промислової установки віброекструзії [5] розмір і кількість віброекструдерів визначалися фізичним моделюванням процесу змішування 3 урахуванням складів базальтофібробетонів.

Для забезпечення якісного змішування в одному апараті застосовуються каскадні віброекструдери $[6,7]$. Але зазначені конструкції забезпечують або невисокий змішувальний ефект, особливо за умови переходу на бетонну суміш іншого якісного та/або кількісного складу, а отже - і невисоку якість продукції [6], або відрізняються надзвичайно складною конструкцією, насиченою значною кількістю нарізних з'єднань, що експлуатуються в абразивному середовищі [7]. 


\section{Матеріали та методи дослідження}

Авторами була запропонована конструкція віброекструдера [8], що містить бункер 13 плоскими стінками 2 - 5, які своїми нижніми ділянками утворюють роздавальне вікно, закріплений на бункері збуджувач коливань 6, а також встановлену в бункеpi по його ширині щонайменше одну пару похилих перегородок 7, причому торцеві плоскі стінки 4, 5 бункера 1 розташовані вертикально, а похилі перегородки кожної пари 7 встановлені з можливістю переміщення по висоті бункера і фіксації на торцевих плоских стінках бункера в заданому положенні (рис. 1). Залежно від властивостей і складу фібробетонної суміші похилі перегородки встановлюють на необхідній висоті, забезпечуючи необхідну ширину отворів між ними і похилими плоскими стінками бункера віброекструдера. При цьому відсутність в об’ємі бункера складних регулювальних пристроїв суттєво підвищує надійність конструкції.

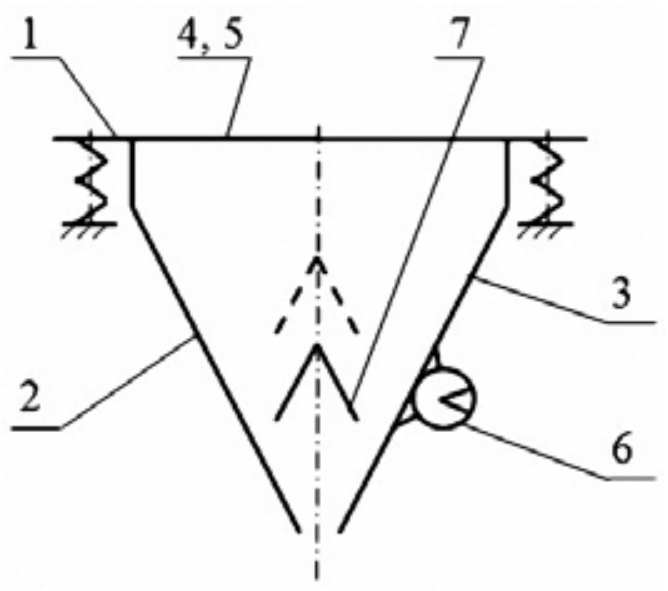

Рис. 1. Схема віброекструдера, що змішує

Запропонована конструкція віброекструдера для змішування може бути використана для широкого діапазону складів фібробетонів. При цьому забезпечується можливість спрощеного регулювання розміру отворів кожного з відсіків бункера, утворених похилими перегородками та стінкою бункера, а отже і підвищена надійність змішувача.

В процесі віброекструзії фібробетону здійснюється природна поздовжня орієнтація фібр за рахунок деформацій зсуву, що виникають при плині композиційного матеріалу у каналі бункера віброекструдера. Остаточне положення фібр у виробі залежить від геометрії каналу бункера віброекструдера. Через те, що зсувні деформації найбільші біля стінок, там буде й найбільша ступінь орієнтування фібр відносно напрямку руху суміші. В центральній частині бункера зсувні деформації і ступінь орієнтування фібр мінімальні.
Для забезпечення кращої поздовжньої орієнтації фібр у центральній частині виробу, а отже і підвищення міцності виробів пропонується спеціальна конструкція віброекструдера для формування фібробетонних виробів [9]. Віброекструдер містить змонтований на пружних опорах бункер 1 зі стінками 2 - 5 і жорстко закріплений на одній з зовнішніх поверхонь або всередині між двох пар похилих дзеркальних перегородок 6, 7 збудник коливань 7 . Дві з'єднані між собою дзеркальні пари похилих перегородок 6, 7 жорстко закріплені у верхній частині бункера і утворюють в зоні живлення два збіжних канали, а у робочій зоні - два розбіжні канали (рис. 2).

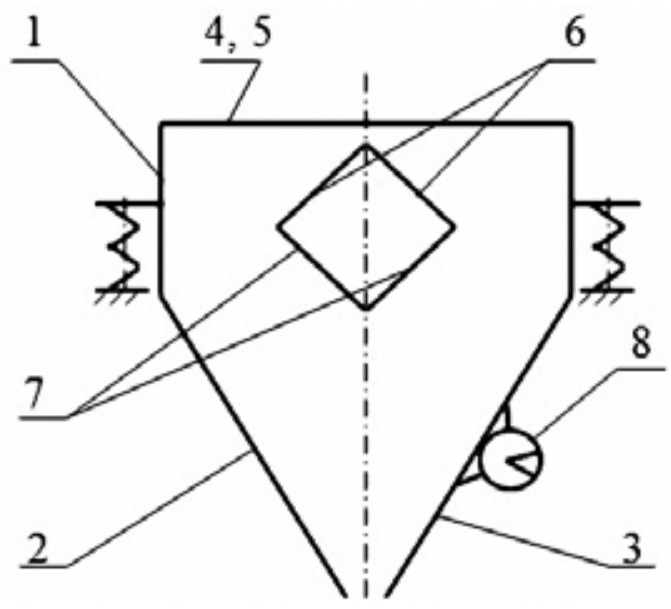

Рис. 2. Схема віброекструдера для формування плоских виробів

Запропонована конструкція дозволяє здійснити більш рівномірне живлення віброекструдера фібробетонною сумішшю, а при плині суміші у розбіжних каналах - збільшити ступінь остаточного орієнтування фібр уздовж осі формування в центральній частині виробу. При наявності розбіжних каналів суміш подається у центральну частину бункера, де зсувні деформації суміші мінімальні (а отже і подальше орієнтування фібр - найменше), вже зі значною орієнтацію фібр. Все це сприяє збільшенню і вирівнюванню поздовжньої орієнтації фібр по перерізу виробу і, відповідно, його якості.

Варіант виконання віброекструдера, коли збудник коливань закріплюється всередині між двома парами похилих дзеркальних перегородок, забезпечує рівномірне передавання вібрації по обидва боки від збудника коливань безпосередньо дзеркальним похилим перегородкам і стінкам бункера. В цьому випадку рівномірність властивостей одержуваної фібробетонної суміші по всьому їі об'єму збільшується, що сприяє одержанню продукції високої якості. 


\section{Результати та їх обговорення}

В процесі віброекструзії плин суміші можна розглядати, як течію у плоских симетричних і несиметричних каналах. Поздовжні перерізи запропонованих конструкцій являють собою низку таких каналів.

При розгляді процесу використовується феноменологічний підхід, який приймає фібробетонну суміш, як однорідне ізотропне середовище, а про структуру суміші робляться лише загальні застереження. Враховується, що вібруючі фібробетонні суміші при віброекструзії являють собою псевдоньютонівські системи. Розрахункові схеми процесу у циліндричних координатах $r, \varphi, z$ наведені на рис. 3. Початок координат, вибраний у точці пер етину ліній, $є$ продовженням похилих стінок каналу. Передбачається, що всі промені, які проходять через початок координат, є лініями плину, а висота шару суміші у каналі при віброекструзії підтримується постійною.

На підставі попередніх досліджень процесу [3, 10] нижче (таблиця 1) пропонуються аналітичні залежності для розрахунку середнього значення деформації зсуву $\bar{\gamma}$ і кута нахилу фібр $\alpha$ відносно осі $r$ в результаті проходження сумішшю відповідного плоского каналу бункера віброекструдера.

Недоліком процесу віброекструзійного змішування у плоских каналах, як і будь-якого ламінарного конвективного змішування, є нерівномірність деформацій зсуву у всьому об’ємі матеріалу.

При розробці нових конструкцій каскадних віброекструдерів необхідне проведення нескладних дослідів, що моделюють процес плину відповідної суміші у плоских каналах і виконання розрахунку за запропонованими формулами необхідної сумарної деформації зсуву, що забезпечує задовільне змішування.

Ступінь поздовжнього орієнтування фібр необхідно задавати окремо для різних виробів залежно від їх призначення, а зміна ступеня орієнтування здійснюється зміною геометрії каналів бункера віброекструдера.

Застосування спеціально розробленого віброекструдера для формування плоских фібробетонних виробів товщиною 40 мм на базовій дослідно-промисловій установці [5] дозволить (за попередніми розрахунками) приблизно на третину покращити поздовжню орієнтацію фібр у виробі.

\section{Висновки}

Конструкція каскадного віброекструдера для змішування, що пропонується, може бути застосована для широкого діапазону складів фібробетонних сумішей, а спеціально розроблений віброекструдер для формування дозволяє значно підвищити поздовжнє орієнтування дисперсної арматури у плоских виробах.

Наведені аналітичні залежності дають можливість кількісного опису відмінностей у деформуванні суміші і остаточного орієнтування фібр у виробах для пропонованих апаратів.

Результати роботи передбачається використовувати при проектуванні нового віброекструзійного обладнання для перемішування фібробетонних сумішей і формування дисперсноармованих виробів.

У подальших дослідженнях за цією темою планується розглянути особливості протікання віброекструзійного процесу при формуванні виробів іншого поперечного профілю.

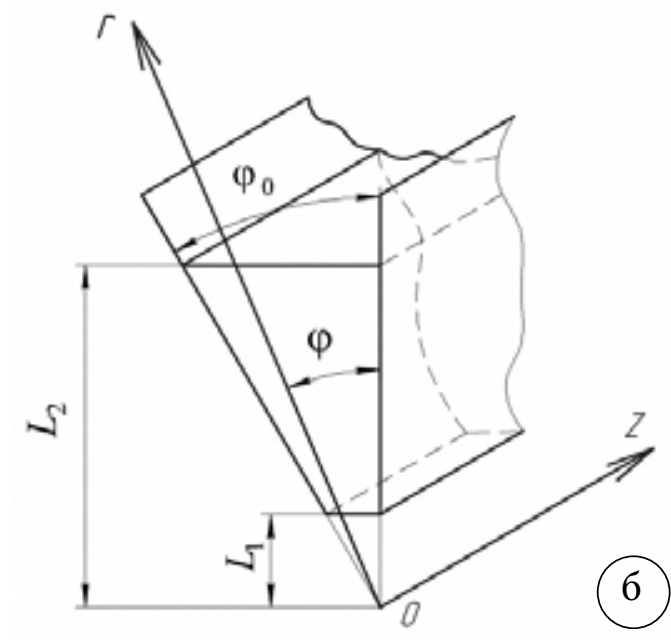

Рис. 3. Розрахункові схеми плину фібробетону у симетричному (а) і несиметричному (б) каналах бункера віброекструдера 
Таблиця 1.

Аналітичні залежності для розрахунку середнього значення деформації зсуву $\bar{\gamma}$

і кута нахилу фібр $\alpha$ відносно осі $r$ в результаті проходження сумішшю відповідного плоского каналу

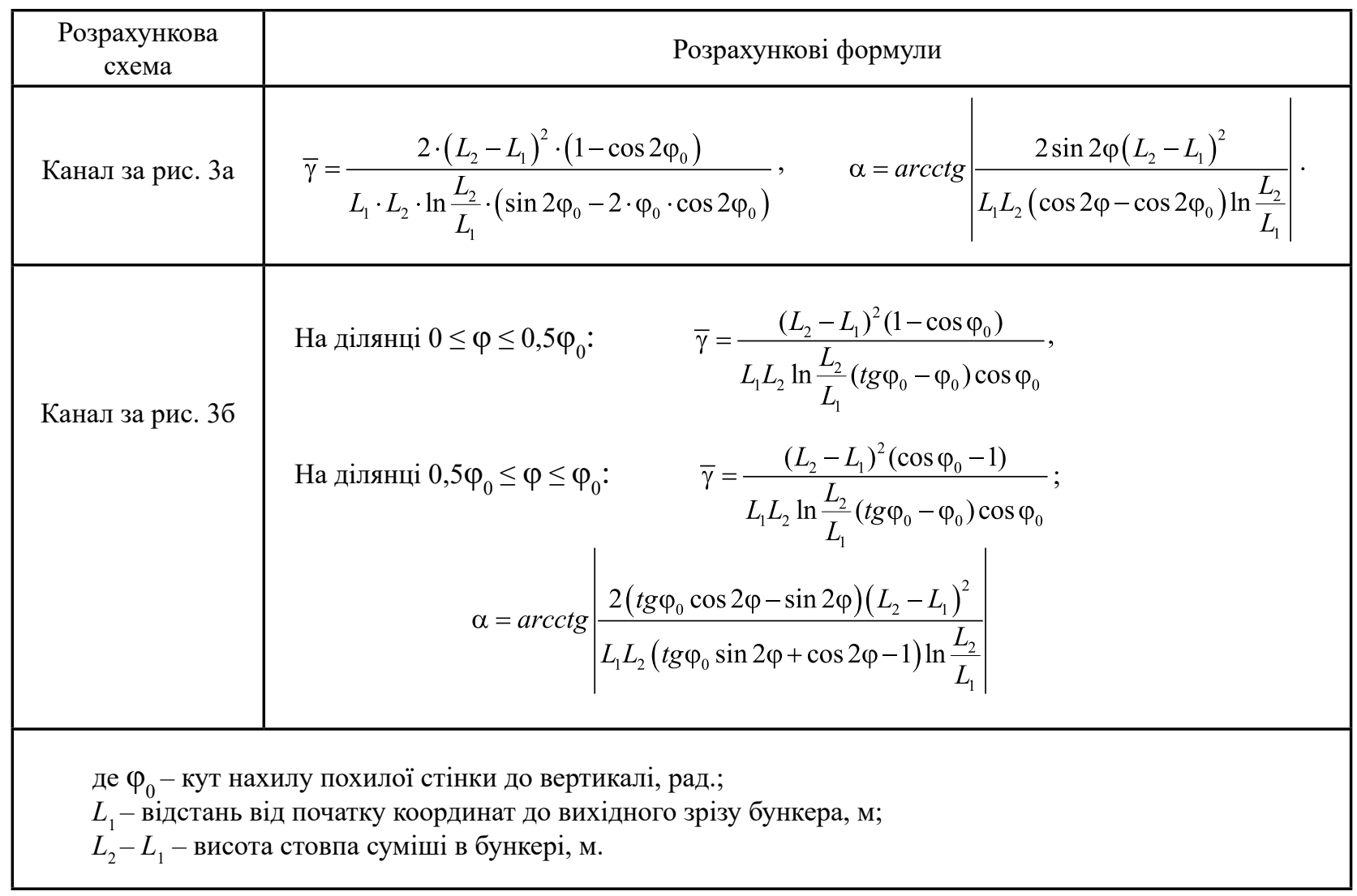

\section{References}

1. Тадмор, З., Гогос, $K$. Теоретические основы переработки полимеров. - М.: Химия. - 1984. - 632 с. 2. Торнер, Р.В. Теоретические основы переработки полимеров. - М.: Химия. - 1977. - 464 с.

3. Андреев, И.А., Лукач, Ю.Е., Магазий, П.Н. Процесс смешения при виброэкструзии фибробетона. Хим. машиностроение: Респ. межвед. науч. - техн. сб. - 1989. - Вып. 49. - С. 34 - 37.

4. Андреєв, І.А., Безугла, Л.О. Особливості віброекструзійного змішування фібробетону в несиметричному каналі. Наукові вісті НТУУ «КПІ». - 2009. № 2. - С. 61 - 65 .

5. Андреєв, І.А., Магазій, П.М., Трач, В.Ю., Дрожжин, Л.М. Формування фібро бетону. Сільське будівництво. - 1986. - № 2. - С. 19.

6. Авторское свидетельство СССР № 1616821. Виброэкструдер для укладки бетонных смесей в форму. Киевский политехнический институт; авт. изобр. Андреев И.А., Лукач Ю.Е., Магазий П.Н., Трач В.Ю. опубл. у бюл. 30.12.1990. - № 48, МПК (5) В28В 13/02.
7. Андреев, И.А., Магазий, П.Н. Вискозиметр для виброэкструдируемого фибробетона. Хим. машиностроение: Респ. межвед. науч. - техн. сб. - 1987. - Вып. 45. - С. 95 - 99.

8. Андреєв, І.А., Безугла, Л.О. Процес змішання фібробетонної суміші у плоскому збіжному несиметричному каналі при віброекструзіі. Наукові праці Одеської національної академії харчових технологій. - Одеса: 2008. - Вип. 32. - С. 44 - 47.

9. Андреєв, I.А., Фурманська, В.В. Ефективність дисперсного армування при віброекструзії фібробетону. Вісник національного технічного університету України "Київський політехнічний інститут", серія „Хімічна інженерія, екологія та ресурсозбереження”. - К.: 2008. - №1. - С. 19 - 22.

10. Андреєв, I.А., Довжик, М.Т. Орієнтування дисперсної арматури під час плину фібробетонної суміші в каналах бункера віброекструдера. Вісник національного технічного університету України “Київський політехнічний інститут”, серія „Хімічна інженерія, екологія та ресурсозбереження”. К.: 2009. - №1(3). - С. 29 - 32. 